Forthcoming in Diego Machuca and Baron Reed, eds., Skepticism: From Antiquity to the Present (New York: Bloomsbury Publishing, 2016)

\title{
A Pyrrhonian Interpretation of Hume on Assent
}

\author{
Donald L. M. Baxter
}

\section{Introduction}

How is it possible for Scottish philosopher David Hume (1711-1776) to be both withering skeptic and constructive theorist? I recommend an answer like the Pyrrhonian answer to the question how it is possible to suspend all judgment yet engage in active daily life. Sextus Empiricus distinguishes two kinds of assent: one suspended across the board and one involved with daily living. The first—active endorsement — is an act of will based on appreciation of reasons; the second - passive acquiescence-is a causal effect of appearances. I suggest that Hume makes the same distinction, only he extends the sort of assent involved in the Pyrrhonian's daily life to theoretical matters as well. ${ }^{1} \mathrm{He}$ is a skeptic both in finding no reason to grant the one sort of assent and in being subject to the other.

Understanding my suggested Hume interpretation requires understanding the Pyrrhonian distinction in Michael Frede's way, which I will explain. To bring out the relevant features of Frede's version, I defend it against the rival version of Myles Burnyeat. Next, I suggest that Hume's version of the distinction is that between belief as an act "of the cogitative part of our natures" and as an act of the "sensitive" part (Treatise

\footnotetext{
${ }^{1}$ My reading follows Popkin (1966) (on Popkin on the crucial influence of Pyrrhonism on modern philosophy in general, see Maia Neto's chapter in this volume). See also Baxter (2006; 2008: ch. 1; 2009a; 2009b). Note that Hume does not follow the Pyrrhonians in their centrally important concern with tranquility. For a detailed discussion of Hume's familiarity with Sextus's works, see Fosl (1998).
} 
[T] 1.4.1.8). ${ }^{2}$ Hume's version can be fleshed out in the way I suggest by regarding it, as Dugald Stewart did, to be derived from a lengthy discussion of Ralph Cudworth's. I then summarize how Treatise 1.4.1, "Scepticism with regard to reason," shows both that active endorsement is never merited and that passive aquiescence cannot be avoided.

Julia Annas hints at an account like the one I give, but does not develop it and ends up reading Hume as a dogmatist (Annas 2000: 276, 279). Instead, I recommend reading Hume as finding no sufficiently good reason for active endorsement of any view while yet yielding passive acquiescence in even some theoretical matters. In theorizing thus concerning the science of man, Hume remains just as much a skeptic as Sextus does in daily life, such as when avoiding precipices or engaging in religious devotions.

\section{Pyrrhonian Kinds of Assent}

The characterization of Pyrrhonism I will give depends heavily on the work of Michael Frede (1997a; 1997b) on kinds of assent. Frede's interpretation is a minority view; the majority view follows the interpretation of Myles Burnyeat (1997a). It will help in understanding Frede's difficult view to contrast it with Burnyeat's. In explaining the key difference between them, as I understand it, I'll focus on Sextus's Outlines of Pyrrhonism. Both Frede and Burnyeat take Sextus to have an answer to the traditional challenge to the skeptic, one famously reiterated by Hume in his Enquiry concerning Human Understanding (EHU 12.23). ${ }^{3}$ Here is the challenge: if you are utterly passive, then you will quickly perish, but if you act to preserve your life, then you must believe something, for all action requires some belief. For instance, you would not eat in response to hunger, if you did not believe that eating would relieve your hunger. This

\footnotetext{
${ }^{2}$ I cite Hume's Treatise by book, part, section, and paragraph. I use the text in Hume (2007).
} 
challenge is generally posed by those who assume that the Pyrrhonian eschews any kind of assent. That assumption is attacked in different ways by both Frede and Burnyeat. Their attacks rely on passages from Sextus such as these:

When we say that Sceptics do not hold beliefs, we do not take 'belief' in the sense in which some say, quite generally, that belief is acquiescing in something; for Sceptics assent to the feelings forced upon them by appearances. ... Rather, we say that they do not hold beliefs in the sense in which some say that belief is assent to some unclear object of investigation in the sciences; for Pyrrhonists do not assent to anything unclear. (

But the main point is this: in uttering these phrases they say what is apparent to themselves and report their own feelings without holding opinions, affirming nothing about external objects. (PH I 15)

As we said before, we do not overturn anything which leads us, without our willing it, to assent in accordance with a passive appearance. ( $\mathrm{PH} \mathrm{I} 19)$

Remember too that we say we neither posit nor reject anything which is said dogmatically about what is unclear; for we do yield to things which passively move us and lead us necessarily to assent. (PH I 193)

\footnotetext{
${ }^{3}$ I cite Hume's Enquiry by section and paragraph. I use the text in Hume (2000).

${ }^{4}$ I follow the translation by Annas and Barnes in Sextus Empiricus (2000).
} 
For his interpretation, Frede distinguishes two kinds of assent. In one way, you do not assent to the view that eating relieves hunger, but in another way you do. Burnyeat does not distinguish two kinds of assent, but rather distinguishes two classes of proposition liable to assent. A rough way to make the distinction is to say that one class consists of propositions beginning with "It appears to me now that ...," where this phrase is used in the course of stating that something is appearing to you and describing how it appears. The other class consists of all the other propositions. Thus the Pyrrhonian who acts to relieve his hunger assents to the proposition "It appears to me now that eating relieves hunger" understood in this way, and not to the proposition "Eating relieves hunger." In making their respective distinctions, both Frede and Burnyeat hold that there are assentings of a sort that is necessary to survival, and assentings of a sort that is not necessary to survival. It is this latter sort of assenting that is at issue in theoretical discussions about unclear matters and that the Pyrrhonian avoids. Thus one can be a Pyrrhonian without perishing.

Four considerations incline me against Burnyeat's view. Appreciating them helps one appreciate the nuances of Frede's interpretation.

It seems to me, first, that assent to "It appears to me now that eating relieves hunger," used to state that one is being appeared to and to describe how, is not sufficient to motivate eating when one is hungry. It can only motivate eating if it leads to some kind of assent to "Eating relieves hunger." One is motivated, generally, not by realizing how the world appears to one, but by taking some sort of stand on how the world is. So Burnyeat's proposal does not solve the problem with survival. Perhaps Burnyeat need not say that assent to "It appears to me now that eating relieves hunger" motivates eating.

\footnotetext{
${ }^{5}$ Or, perhaps better, propositions perspicuously paraphrased by propositions beginning with 'It appears to
} 
Rather, the appearance that prompts that report also directly motivates eating. ${ }^{6}$ However, for the direct motivation to happen, the content of the appearance must be "Eating relieves hunger." Being moved by this appearance will be just like the kind of assent necessary for survival that Frede defends. So this defense of Burnyeat would be a concession to his opponent.

It seems to me, second, that the Burnyeat interpretation is not forced by the text. True, Sextus says that the skeptics will only say "what is apparent to themselves, and report their own feelings, affirming nothing about external objects." But I think that often the phrase "It appears that..." is not used to state and describe, but rather is used to qualify one's assent to the proposition in its scope. If I say, "It appears to me now that eating relieves hunger," I am assenting to "Eating relieves hunger" with reservations. Perhaps I suspect that I have not established its truth conclusively. Or, more to the point, perhaps I am just reporting the view which is striking me now-that eating relieves hunger-without making any commitments to there being any good reason to hold that view. So, when skeptics say what is apparent to themselves, they need not be unreservedly endorsing that they are appeared to a certain way; they may rather with maximum reservation be venting the view that things are that way (PH I 13, 15). ${ }^{7}$ Thus there is a natural alternative to Burnyeat's way of interpreting Sextus's frequent appeals to how things appear.

This alternative is not exactly what Frede terms the "epistemic sense" of 'appears', if in that sense 'it appears to me' is synonymous with 'I think' or 'I believe'. These locutions can sometimes express assent with reservations, but do not always

\footnotetext{
me now that ...'

${ }^{6}$ I'm grateful to Lionel Shapiro for this suggestion.
} 
express that. I am reluctant to use the word 'belief' to characterize assent with reservations as I elucidate it. In his earlier paper, Frede suggests that the skeptic has beliefs, though it becomes apparent that Frede is using an elastic sense of 'belief' that could include even an impression we don't object to (Frede 1997a: 10, 21-22). I think this way of putting things went too far and was corrected in his later paper.

It seems to me, third, that Frede's view makes better sense than Burnyeat's of Sextus's claims that the skeptical phrases "cancel” themselves (PH I 14-15, 206). Phrases such as "In no way more" or "No more this than that" mean that anything and its negation are equally convincing, and so anything is unconvincing-it leaves the judgment suspended. As Sextus says, "Everything is no more so than not so." This utterance applies to itself, and so the skeptics make clear that they suspend judgment even concerning their own utterances. This is the sense in which the phrases "cancel" themselves. Each phrase says in part that it itself is unconvincing. However, if skeptical phrases implicitly have the content that Burnyeat would think they do, then there would be no self-cancelling. The sentence "It appears to me now that everything is equally convincing and unconvincing," if true, does not entail that everything is unconvincing. So it does not entail that it itself is unconvincing. So it does not cancel itself.

In a footnote, Burnyeat notices a related problem with self-cancelling. He says that Sextus's self-cancelling propositions have to make a truth claim to be self-cancelling, whereas, according to Burnyeat elsewhere, reports of appearances make no truth claim (1997: 30-31). ${ }^{8}$ Therefore, one infers, Sextus's self-cancelling phrases cannot be reports

\footnotetext{
${ }^{7}$ Cf. Sellars (1956: sec. 16). Wittgenstein (1958: 92) says: "Don’t regard a hesitant assertion as an assertion of hesitancy."

${ }^{8}$ Barnes (1997: 65 n. 21) disagrees. Burnyeat uses the term 'self-refuting' instead of 'self-cancelling'.
} 
of appearances interpreted Burnyeat's way. However, Burnyeat sees it as a problem for Sextus, not for his own interpretation (Burnyeat 1997a: 54 n. 52).

Fourth, while both interpretations grant some kind of assent to what is apparent, Frede's makes better sense of the skeptic's practice of continuing to investigate whether what is apparent is real. If, say, "Honey sweetens" is what is apparent, then it makes sense to investigate whether "Honey sweetens" is really true (프 I 19). However, if "It appears to me now that honey sweetens" is what is apparent, understood the way Burnyeat intends, then there is nothing to investigate beyond the fact that you are appeared to in that way.

Burnyeat might reply that what one investigates is whether the state or impression avowed when one says "It appears to me now that honey sweetens" conforms to reality. However, this response acknowledges my point. For a state to conform to reality is for the proposition it contains to be true. So the object of investigation is whether "Honey sweetens" is true, not whether "It appears to me now that honey sweetens" is true.

Thus, I incline to Frede's interpretation of Sextus. In any event, Frede's approach to Sextus provides an extremely fruitful way of resolving a perennial problem in Hume interpretation- how to reconcile Hume the skeptic with Hume the scientist of Man-in a way that does justice both to the power of Hume's skeptical arguments and to the scientific aspirations of Hume's psychological theory. So I recommend assuming that Frede has Sextus right, for the purpose of understanding Hume.

Sextus distinguishes two kinds of assent. Here I will give my own understanding of the distinction rather than try accurately to represent Frede's. Call the two kinds of assent 'active endorsement' and 'passive acquiescence'. The first is to actively endorse a view as true for a reason that one appreciates to be sufficiently good. The second is to 
passively acquiesce in a view forced upon one by appearances. 'View' can mean the mental state one has in entertaining a proposition that is a candidate for being assented to, but I mean the proposition itself. ${ }^{9}$

An example of active endorsement might be the firm conviction of a mathematician in the result of a proof on which he has labored long and carefully and which has received the approbation of his peers. Another might be the unshakeable conviction of a religious zealot who considers his faith's scriptures to be self-justifying. These examples are not conclusively examples. Active endorsement will, for Hume, turn out to be a fiction that we and his opponents often believe in, but without good reason. In any event, the examples are helpful at this stage in seeing what the contrast with passive acquiescence is supposed to be. Because of the self-conscious attempt to reason as one ought to, active endorsement has greater pretensions than everyday belief. Its natural home, if it has any, would be enterprises in which one investigates unclear matters beyond the mundane concerns of daily life. Crucially, belief is supposed to be chosenchosen because one understands that it is what one ought to believe. In this sense it is called active.

Passive acquiescence, on the other hand, has no more pretension than everyday belief, and sometimes less. In passively acquiescing one goes along with the view that strikes one without making any decision one way or the other about its legitimacy. For example, if a crowd stampedes by shouting, "The dam has broken!" you might well run along without stopping to consider whether or not this could be true. Circumstances just sweep you into acting as if the view that the dam has broken were indeed true (cf. Thurber 1942: 22). Passive acquiescence is acting as if a belief were true without

\footnotetext{
9 'Belief' encompasses a similar ambiguity between mental state and its propositional content.
} 
deciding that it is. In this respect, it is like conjecture, pretense, supposition, and taking as a working hypothesis. When a two year old pretends that a countertop is a sink, going through the motions of washing her hands and declaring, "This is a real sink," no one, least of all her, is fooled. She has not decided that what she says is true, but acts as if it is true for all that. So do people taking the other attitudes I've listed. A member of a committee, who uncharitably suspects a fellow member of being disingenuous, might take as a working hypothesis that the other member is acting in good faith. The result might predictably be greater peace of mind for hypothesizer and a better outcome for the committee. Pursuing these practical benefits is not the same as deciding in favor of the truth of the hypothesis. Similarly, passive acquiescence in a view is a matter of acting as if the view is true. However, there is a major difference from the attitudes I just mentioned. They are chosen. Passive acquiescence, on the other hand, is not the result of willing. It is a causal effect of how things strike one. In this sense it is passive.

The best examples of passive acquiescence would be the "beliefs" of animalsfor instance, those of the little pig admired by Pyrrho (DL IX 68, 481). Animal beliefs are beliefs only in an analogous sense, not being governed in any way by normative considerations. Instead, they are brought about by some sort of instinctual response to circumstances.

It is with respect to active endorsement that a Pyrrhonian suspends judgment. He finds that for any argument for any conclusion, he is able to find an apparently equally good argument for a conflicting conclusion. This balancing of arguments leaves him disinclined to either side, resulting in a suspense of judgment, i.e., no active endorsement 
either way. ${ }^{10}$ After all, active endorsement is meant to be the kind of assent that results from reasoning as you ought to in the recognition that you are reasoning as you ought to. One cannot arrive at this kind of assent when one has an equally good reason to endorse something conflicting.

This method of balancing conflicting arguments is central to the Pyrrhonian enterprise, even when Pyrrhonians take pains to lay out all-purpose arguments against any conclusion. For instance, take the argument that (i) nothing should be believed without a reason, and (ii) any conclusion is believed either for no reason, or a circular reason (which is no reason), or a vicious infinite regress of reasons (which is no reason)

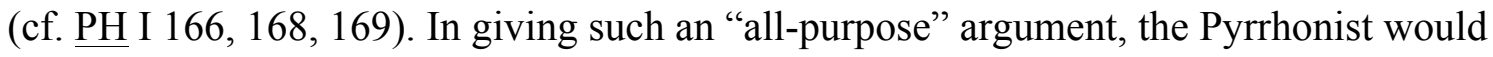
be taking for granted that there would be some consideration in favor of the other side, which needed to be counterbalanced. The result is suspense of active endorsement. ${ }^{11}$

Generally, it is investigations into unclear matters, such as those investigated in philosophy, science, mathematics, and religion, in which one would seek to actively endorse a view. In such investigations one is self-reflectively trying to find good reasons for granting assent. In daily life, when one is for the most part just reacting for practical purposes to the way things appear, one does not strive to meet the high standards of active endorsement.

As the Pyrrhonian continues to investigate, his ability to balance every argument with something conflicting has its effect on him. It begins to appear as if no proposition deserves active assent. As Sextus puts it, "Thus what is said is this: 'All of the unclear

\footnotetext{
${ }^{10}$ I disagree with Burnyeat's claim that this process could happen only if the skeptic comes to the belief that "contrary claims are equal" (Burnyeat 1997a: 56) The skeptic need at most acquiesce in this appearance, and perhaps, as Barnes urges, the suspense of judgment "simply happens to us" (Barnes_1997: $58-59)$.
} 
matters investigated in dogmatic fashion which I have inspected appear to me inapprehensible"' (PH I 200). He, of course, does not actively endorse this view, but it governs his actions nonetheless. Now, it seems natural to say that he passively acquiesces in this view. However, it seems to me that the view concerns a theoretical matter about something that is not obvious, even if giving an appearance. Note that not all appearances are sensory appearances (Frede 1973: 809). For example, Sextus says that the Pyrrhonians accept the appearance "that piety is good and impiety bad" (PH I 23). Thus, the door seems opened to Hume's extension of passive acquiescence into theoretical matters beyond active daily life (Popkin 1966: 95; Norton 1982: 268 n. 48). ${ }^{12}$ The skeptic's view seems forced on him by appearances. Hume develops and extends this notion of views forced by appearances.

\section{Humean Kinds of Assent}

Hume's account echoes the Pyrrhonian's distinction between two kinds of assent and the appeal to appearances forcing views on one. Hume (T 1.4.1.8) explicitly makes the distinction between two kinds of assent: belief as an act of the "cogitative part of our natures" or as a "simple act of the thought" versus "belief as an act of the sensitive ... part of our natures."

It is not immediately apparent that Hume's distinction maps onto active endorsement and passive acquiescence in the way I'm suggesting. However, evidence is provided by historical context. Dugald Stewart (2005: 219) points the way, noting that

\footnotetext{
${ }^{11}$ For a similar approach to “Agrippa's Trilemma," see Williams (1988: 573-583), though Williams sees the results of the modes of Agrippa as denials of specifically epistemological theses that would be held by a dogmatist, whereas I see them as in conflict with any conclusion assented to for a reason.
} 
the distinction in Hume is familiar from the work of Ralph Cudworth. Cudworth spends much time developing the distinction:

Wherefore it is evident from what we have declared, that there are two kinds of Perceptive Cogitations in our Soul: the one Passive, when the Soul perceives by suffering from its Body, and the Objects without; the other Active, when it perceives by its exerting its own Native Vigor from within it self. $(1731: 4.1 .7)^{13}$

Cudworth explicitly connects the first with appearance, when he observes that "the Nature of Sense consists in nothing else but meer Seeming or Appearance” (1731: 3.4.2). In the previous section, he connects this sense of 'appearance' with Sextus. He then concludes,

And therefore we can have no Certainty by Sense alone either concerning the Absolute Natures of Individual Corporeal things without us, nor indeed of their Existence; but all the Assurance that we have thereof arises from Reason and Intellect judging of the Phantasms or Appearances of Sense, and determining in which of them there is an Absolute Reality, and which of them are but meerly Relative or Phantastical. (1731: 3.4.8)

As opposed to the passive appearances of sense,

\footnotetext{
12 "In vain would the skeptic make a distinction between science and common life, or between one science and another. The arguments employed in all, if just, are of a similar nature and contain the same force and evidence" (Hume 1980: 9-10).
} 
Knowledge is an Inward and Active Energy of the Mind it self, and the displaying of its own Innate Vigour from within, whereby it doth Conquer, Master and Command its Objects, and so begets a Clear, Serene, Victorious, and Satisfactory Sense within it self. (1731: 4.1.1)

Cudworth finds the origin of the distinction in Plato's Theatetus (1731:3.3.6). He may well have found some confirmation and development in Descartes's Meditations:

When I say "Nature taught me to think this," all I mean is that a spontaneous impulse leads me to believe it, not that its truth has been revealed to me by some natural light. There is a big difference here. (AT VII 38$)^{14}$

Three paragraphs later Descartes distinguishes the basis of belief formed by "blind impulse" from that formed by "reliable judgment." He seems to be making a point captured by Cudworth as follows:

For Knowledge is not a Knock or Thrust from without, but it consisteth in the Awakening and Exciting of the Inward Active Powers of the Mind. (1731: $3.3 .5)^{15}$

\footnotetext{
${ }^{13}$ I cite Cudworth (1731) by book, chapter, and section.

${ }^{14}$ I follow the translation in Descartes 1984.

15 "[T] $]$ hat all our Cogitations, are Obtruded, and Imposed upon us from without; and that there is no Transition in our Thoughts at any time, but such as had been before in Sense; (which the Democritick Atheist averrs) this is a Thing, which we absolutely deny. For, had we no Mastery at all over our Thoughts, but they were all like Tennis Balls, Bandied, and Struck upon us, as it were by Rackets from without; then could we not steadily and constantly carry on any Designs and Purposes of Life" (Cudworth 1964: 845).
} 
Hume ( $\mathrm{T}$ 1.4.1), in contrast, when making this kind of distinction will be taking the side of the "Knock or Thrust from without." He contended that belief in persons is like that in animals: an instinctual effect of observation and experience given the principles of nature ( $\mathrm{T}$ 1.3.16). The argument in section 1.4.1 supports his earlier contention. His purpose in this section is to argue that if we reasoned as we ought to, and if belief were a cogitative act, we would not assent to anything. Since we do assent to some things, there must be some other explanation for it than reasoning as we ought to. Belief is rather an act of sensation - an addition of "force and vivacity" — naturally caused in us by customary connections observed in the past (T 1.3.7). Here is Hume's innovation. The sensitive part of our nature responds to the impulse from without not only with images, but also with a feeling of their forcefulness. In his argument, he intends "to make the reader sensible of the truth of my hypothesis, that all our reasonings concerning causes and effects are deriv'd from nothing but custom; and that belief is more properly an act of the sensitive, than of the cogitative part of our natures" (T 1.4.1.8).

Think of it this way: judgment consists of a content plus assent (see Descartes, Meditations, AT VII 56-58). The question is, is the assent an action one does or something one suffers? Hume picks the latter.

Hume's argument begins with the Diminution Argument that all belief depends on probable reasoning, ${ }^{16}$ and after every case of probable reasoning "we are oblig'd by our reason" to weigh in a small measure of uncertainty about whether the reasoning in that case was properly done. Drawing a conclusion, by weighing considerations for and against it, always introduces an additional consideration against it —one that ought to be weighed in. That is because our faculty for weighing considerations has introduced its

\footnotetext{
${ }^{16}$ Even beliefs not initially arrived at by reason are subject to its scrutiny.
} 
own errors in the past, independent of the original considerations themselves. The additional consideration needs to be weighed in. So every weighing requires a reweighing. Weighing in an additional consideration against a conclusion diminishes one's confidence in the conclusion. So every reweighing diminishes confidence in the conclusion. But every reweighing is itself a weighing, so requires a further reweighing. So, confidence in the conclusion will be diminished to extinction during the successive reweighings. For Hume, like any skeptic, diminishment of confidence in a conclusion does not increase confidence in its negation. Nor, for Hume, is there some kind of negative assent, i.e., dissent, that can begin to increase; there is no negative vivacity of ideas. So, the result will be suspense of judgment. Hume concludes, therefore, that reasoning as we ought will leave us in suspense of judgment: "all the rules of logic require a continual diminution, and at last a total extinction of belief and evidence" ( $\mathrm{T}$ 1.4.1.6).

Don Garrett argues "that Hume offers no epistemic evaluation in concluding that 'all the rules of logic' require a total extinction of belief." Hume, rather, is merely explaining how our natural faculty of reason would operate if unhindered by "the imagination's difficulty in following the 'subtle and refin'd reasoning' of such repeated reflections" (1997: 228). However, Hume is indeed offering an epistemic evaluation: one that it strikes him we should and would endorse if we were able to reason as we ought. The whole section, as well as the Diminution Argument itself, begins by considering how we ought to reason in our pursuit of truth. To minimize our chance of error, we ought to take our own fallibility into account when settling on the degree of assurance we should have in our conclusion. "In every judgment, which we can form concerning probability, as well as concerning knowledge, we ought always to correct the first judgment, deriv'd 
from the nature of the object, by another judgment, deriv'd from the nature of the understanding" (T 1.4.1.5). Note the "ought" and the ensuing "correct." It is an epistemic 'ought' because the goal is truth and avoidance of error ( $\mathrm{T}$ 1.4.1.1). Again, Hume concludes that, if we reason as we ought to in pursuit of truth, we will lose all assurance through our repeated corrections.

Many scholars think Hume's Diminution Argument fails, but that is beside the point here. ${ }^{17}$ It strikes him forcefully that it succeeds. It is an "all-purpose" argument that can counterbalance the considerations in favor of any other view. Consequently, like the Pyrrhonians, Hume is unable to find anything that one ought to choose actively to endorse.

Note that the conclusion itself is one of the propositions it applies to. The conclusion itself is subject to diminution. So even in his own conclusion Hume has found nothing one ought to assent to.

Suppose that belief were active endorsement. We would believe just as we ought. So without anything we ought to assent to, there would be no belief. "If belief, therefore, were a simple act of the thought, without any peculiar manner of conception, or the addition of a force and vivacity, it must infallibly destroy itself, and in every case terminate in a total suspence of judgment" (T 1.4.1.8).

However, we cannot and do not suspend all belief as we ought to. We have lots of beliefs. Among other things, Hume assents to the conclusion of the Diminution Argument, at least during T 1.4.1 and at 1.4.7.7. Still, he says he is not able to believe it "sincerely and constantly," which may mean that sometimes he does not believe it, but

\footnotetext{
${ }^{17}$ For some crucial discussions of the 1.4.1 argument in addition to Garrett's, see Morris (1989: 39-60), Owen (forthcoming), and Fogelin (1985: ch. 2).
} 
more likely means that he is never able to act on it (T 1.4.1.7). ${ }^{18}$ In any event, we have beliefs, therefore belief is not an act of the cogitative part of our soul but is rather an act of the sensitive part. Belief is a matter of being caused to have lively ideas. It is a brute fact about us that, however much we might see the justice of the Diminution Argument, we cannot consistently follow it out for any given proposition. We quickly become overtaxed and almost as quickly return to belief in the convictions we were questioning. That is because “Nature, by an absolute and uncontroulable necessity has determin'd us to judge as well as to breathe and feel" (T 1.4.1.7). We cannot suspend all assent whatsoever any more than a sighted person can prevent himself from seeing his environs with eyes directed to them and open in the sunshine. In making the origin of all belief causal, Hume is echoing the Pyrrhonian view of passive assent as assent to views forced upon us by appearances. The "forcing" is a matter of finding ourselves to have the view in a way independent of the exercising of our will. ${ }^{19}$

One might wonder why Hume would propose the rules for causal reasoning in 1.3.15 if he thinks we cannot reason as we ought. Why would he propose standards for reasoning if we cannot follow such standards? The answer is that his proposed standards for judging of causes and effects are ultimately practical standards, extensions of Sextus's standards of action ( $\underline{\mathrm{PH}}$ I 21-24). They are how we should reason given Hume's Title Principle, as Garrett has termed it: "Where reason is lively, and mixes itself with some

\footnotetext{
${ }^{18} \mathrm{Cf}$. the belief that one ought not believe in body, where "carelessness and in-attention" prevent the opinion from being held constantly (T 1.4.2.56-57).

${ }^{19}$ Thus I agree with Morris that Hume attacks "the intellectualist model of the rationally reflective epistemic agent" in order to replace it with a naturalistic model (Morris 1989: 56). See also Baier (1991: 59-61) and Owen (1999: 120-121). However, all three focus on a conception of reason as a discoverer of necessary connections. I take Hume to rather be arguing that an active endorser-someone who arrives at assent by choosing to reason as he ought — will not arrive at assent. Only assent that is a feeling caused by appearances can survive reasoning. Baier (1991: 96) contends in contrast that reason on Hume's own account has normative authority because it can bear its own survey. Thus Hume discovers "which mental
} 
propensity, it ought to be assented to." Whence the 'ought'? In order not to "be a loser in point of pleasure; and this is the origin of my philosophy" (T 1.4.7.11-12). The rules for causal reasoning are meant to guide our natural propensity to use induction. But they do not address the skeptical problem that we can find no sufficiently good reason to regard the results of induction as true ( $\mathrm{T}$ 1.3.6.11). We are able to follow standards gleaned from natural ways of reasoning in service of practical goals. These practical standards for regarding some things as true or false are the "measures of truth and falshood" that Hume implies that we have (T 1.4.1.7). What we are unable to follow with any stable result are the epistemic standards we aspire to. Instead of losing all assurance, as we epistemically should, we retain some. As he puts it later, "After the most accurate and exact of my reasonings, I can give no reason why I shou'd assent to it; and feel nothing but a strong propensity to consider objects strongly in that view, under which they appear to me" ( $\mathrm{T}$

\subsubsection{3).}

Thus in 1.4.1 Hume finds himself in the position of unavoidably believing things that it strikes him he wouldn't believe if he reasoned as he ought, and so epistemically ought not believe. Readers of Hume who resist the Pyrrhonian interpretation crucially assume that no one can consistently be in such a position. ${ }^{20}$ It seems to such readers that assenting to a view is implicitly committing oneself to its epistemic merit. ${ }^{21}$ However, the distinction between the two kinds of assent is precisely intended to explain how one

\footnotetext{
causes are good reasons." I agree instead with Owen (1994: 198) that 1.4.1 precisely shows that even Humean reason cannot bear its own survey.

${ }^{20}$ For instance, Garrett $(2007: 7,8,11)$ assumes (i) that in providing psychological explanations, Hume has no reason to dispute them, (ii) that coming to believe according to the Title Principle could satisfy one's curiosity only if it epistemically ought to, and (iii) that concluding that one's own beliefs were not probable would undermine one's ability to make judgments about usefulness. All these make the deep assumption that one can't believe things without believing one epistemically ought to believe them.

${ }^{21}$ My thinking here was sparked partly by Patrick Greenough's lecture entitled "Pragmatics in Thought: The Case of Moore's Paradox," University of Connecticut, October 2010.
} 
consistently can believe things that one realizes he epistemically ought not assent to, whether actively or passively. I'll discuss the two possibilities in turn.

First, one can passively acquiesce in things for which one finds no reason sufficiently good for active endorsement. Passively acquiescing in views forced upon one by appearances just is a way to assent without regard to whether one epistemically ought to assent. So one violates no implicit commitment to the epistemic merit of the views in recognizing that one can find none.

Now, if one is to be such a "fool," Hume observes, as are "all those who reason or believe," he should at least be so in a way that is "natural and agreeable" as captured by the Title Principle (T 1.4.7.10-11). ${ }^{22}$ By acquiescing in the Title Principle, Hume decides for practical reasons not to try to conform to onerous epistemic requirements. He is better off ignoring such requirements for the sake of "service to mankind" and his "own private interest" ( $\mathrm{T}$ 1.4.7.10). So, secondly, he is able to passively acquiesce in views even while also passively acquiescing in the view that he epistemically ought to lose all assurance whatsoever. The Diminution Argument with its general conclusion strikes him as successful, and yet he finds he cannot use that result to extinguish any given actual belief. He finds no practical reason why he should even make the effort. And not doing so violates no commitment implicit in his assent, as it would if he were actively endorsing. Again, active endorsement is committing oneself to following the strictures of what one epistemically ought to hold. It would be inconsistent to actively endorse a view when one thought one epistemically shouldn't. But in passively acquiescing in views forced upon

\footnotetext{
${ }^{22}$ His belief in body is another example of Hume's believing something that he realizes he epistemically ought not believe. "Carelessness and in-attention" are our only way to retain any sort of assent in the vulgar view involving "gross illusion" and the philosophical view "loaded" with an "absurdity" (T 1.4.2.56-57). Even were the Title Principle an epistemic one, it could not justify the conclusion that forgetting or ignoring a problem is a solution to it.
} 
one, one does not make such commitments. So in passively acquiescing in views despite passively acquiescing in the view that he shouldn't, Hume violates no implicit commitment.

That beliefs are caused by appearances, not chosen for their merits, remains true even if we make theoretical investigations. We can voluntarily make observations, do experiments, weigh opposing considerations, etc. ${ }^{23}$ But Hume's point is that the process will cause us to come to a conclusion. It will not be the occasion for our freely choosing which conclusion to come to. And we cannot just will away the resulting belief. Granted, our will could set in motion a process of further weighing of other considerations that could be expected to reduce our assent, or even eliminate it. But the assent itself happens to us, rather than is willed by us. In that way it is passive.

To appreciate this point, the content of the proposition assented to must be distinguished from the kind of assent. Theoretical content does not entail active endorsement. Nor does normative content. Hume can even assent to propositions of the form, "It is evident that ...", or "It is true that ...", or "One ought to believe that ..." without actively endorsing them ( $\mathrm{T}$ 1.4.7.15). His assent is wrung from him by appearances, by how matters strike him, and so is passive acquiescence.

This passive view of assent is nicely summarized, in the Treatise:

We may, therefore, conclude, that belief consists merely in a certain feeling or sentiment; in something, that depends not on the will, but must arise from certain determinate causes and principles, of which we are not masters. (T Appendix 2) 
And also in the first Enquiry:

It follows, therefore, that the difference between fiction and belief lies in some sentiment or feeling, which is annexed to the latter, not to the former, and which depends not on the will, nor can be commanded at pleasure. It must be excited by nature, like all other sentiments; and must arise from the particular situation, in which the mind is placed at any particular juncture. (EHU 5.11)

Note that passive acquiescence ought not be thought of as weak assent. The assent may be normatively weak, but may well be causally "strong and steady" (T 1.3.7.5 n. 20). Hume allows, as Sextus apparently did not, that some views forced upon one by appearances may be causally hard to dislodge ( $\underline{\mathrm{PH}}$ I 230). Force and vivacity come in degrees and sometimes in a very high degree ( $\mathrm{T}$ 1.3.13.19).

I've said that Hume is like the Pyrrhonians in finding insufficiently good reason for active endorsement and in yielding to passive acquiescence. But where exactly is the skeptic's suspense of judgment? It might seem trivial to claim that Hume suspends active endorsement, when he thinks there is no such thing. Why does withholding an assent impossible to grant make him a skeptic? The answer is that, when he reasons as carefully as he can with truth as the goal, he finds no sufficiently good reason why he ought to believe anything. This process leads to temporary suspension of passive acquiescence, until his natural propensities to believe reassert themselves. But it also leads to stable passive acquiescence in the view that those skeptical arguments are unanswerable, even if they produce no lasting suspension of judgment as passive acquiescence. So were active

\footnotetext{
${ }^{23}$ In this respect Hume is allowing for a Pyrrhonian way to accommodate the procedures of the New
} 
endorsement possible, Hume would find it suspended. And for those who believe in active endorsement, they either ought to suspend it or else ought to admit with Hume that their assent is really nothing more than passive acquiescence, after all.

In summary, reasoning as we ought to would result in total suspense of judgment. Were there such a thing as active endorsement, we would totally suspend it, since we can find nothing worthy of it. Nonetheless, passive acquiescence is compelled in us by appearances, even appearances that result from theoretical investigation. In this way Hume can combine his radical skepticism with his constructive science, mathematics, and philosophy. He does so in a way very like the way the Pyrrhonian combined radical skepticism with the assent required to live a normal life.

It is true that Hume resists calling his skepticism Pyrrhonian, and calls it mitigated. But Hume erroneously took the Pyrrhonians to recommend no assent whatsoever, which is why he thought that a true Pyrrhonian must "remain in total lethargy" and soon "perish." As we have seen, the Pyrrhonians had a ready answer to this charge in the distinction between two kinds of assent. They found no reason to grant active endorsement, but yielded to passive acquiescence in order to survive. Likewise Hume. There is no mitigation of his failure to find a sufficiently good reason to actively endorse anything; there is much natural mitigation of any great loss of passive acquiescence that might result from his skeptical arguments (EHU 12.23-25). Hume's own one-sided view of the Pyrrhonians should not prevent our seeing him as their natural successor concerning assent. ${ }^{24}$

Academy (PH I 227-229).

${ }^{24}$ I'm grateful to Richard Bett for penetrating comments in a symposium at the American Philosophical Association Central Division Meetings, 2012, as well as to Diego Machuca and Baron Reed for their helpful suggestions. 


\section{References}

Annas, Julia. 2000. "Hume and ancient scepticism,” Acta Philosophica Fennica 66: 271285.

Baier, Annette. 1991. A Progress of Sentiments. Cambridge, MA: Harvard University Press.

Barnes, Jonathan. 1997. “The beliefs of a Pyrrhonist.” In Burnyeat \& Frede 1997, 58-91.

Baxter, Donald L.M. 2006. "Identity, continued existence, and the external world." In S. Traiger (ed.), The Blackwell Guide to Hume's Treatise, 114-132. Oxford: Blackwell Publishing.

— 2008. Hume's Difficulty: Time and Identity in the Treatise. New York: Routledge.

- 2009a. "Hume's theory of space and time in its skeptical context." In D. F. Norton \& J. Taylor (eds.), The Cambridge Companion to Hume, 2nd. edition, 105-146. Cambridge: Cambridge University Press.

_.2009b. "Précis of Hume's Difficulty," Philosophical Studies 146: 409-411.

Burnyeat, Myles. 1997a. “Can the sceptic live his scepticism?” In Burnyeat \& Frede $1997,25-57$.

—. 1997b. "The sceptic in his place and time." In Burnyeat \& Frede 1997, 92-126.

Burnyeat, Myles and Michael Frede (eds). 1997. The Original Sceptics: A Controversy. Indianapolis: Hackett Publishing.

Cudworth, Ralph. 1731. A Treatise concerning Eternal and Immutable Morality. London: James and John Knapton. 
—. 1964. The True Intellectual System of the Universe. Stuttgart-Bad Cannstatt: Friedrich Frommann Verlag.

Descartes, René. 1984. Meditations on First Philosophy. In J. Cottingham, R. Stoothoff, and D. Murdoch (eds.), The Philosophical Writings of Descartes, Vol. 2, 1-90. Cambridge: Cambridge University Press.

Fogelin, Robert. 1985. Hume's Skepticism in the Treatise of Human Nature. London: Routledge \& Kegan Paul.

Fosl, Peter. 1998. “The bibliographic bases of Hume's understanding of Sextus Empiricus and Pyrrhonism," Journal of the History of Philosophy 36: 261-278.

Frede, Michael. 1973. Review of C. L. Stough, Greek Skepticism: A Study in Epistemology, The Journal of Philosophy 70: 805-810.

—. 1997a. "The sceptic's beliefs." In Burnyeat \& Frede 1997, 1-24.

_ 1997b. "The sceptic's two kinds of assent and the question of the possibility of knowledge.” In Burnyeat \& Frede 1997, 127-151.

Garrett, Don. 1997. Cognition and Commitment in Hume's Philosophy. New York: Oxford University Press.

_. 2007. "Reasons to act and believe: naturalism and rational justification in Hume's philosophical project," Philosophical Studies 132: 1-16.

Hume, David. 1980. Dialogues concerning Natural Religion, R. H. Popkin (ed.). Indianapolis: Hackett Publishing.

- 2000. An Enquiry concerning Human Understanding, T. L. Beauchamp (ed.). Oxford: Clarendon Press.

- 2007. A Treatise of Human Nature, D. F. Norton and M. J. Norton (eds.). Oxford: Clarendon Press. 
Morris, William Edward. 1989. "Hume's scepticism about reason,” Hume Studies 15: 39-60.

Norton, David Fate. 1982. David Hume: Common-Sense Moralist, Sceptical Metaphysician. Princeton: Princeton University Press.

Owen, David. 1994. "Reason, reflection, and reductios," Hume Studies 20: 195-210.

—. 1999. Hume's Reason. Oxford: Oxford University Press.

—. Forthcoming. "Scepticism with regard to reason." In D. Ainslie (ed.), The Cambridge Companion to Hume's Treatise. Cambridge: Cambridge University Press.

Popkin, Richard. 1966. "David Hume: his Pyrrhonism and his critique of Pyrrhonism.” In V.C. Chappell (ed.), Hume, 53-98. Garden City, NY: Anchor Books.

Sellars, Wilfrid. 1956. "Empiricism and the philosophy of mind." In H. Feigl and M. Scriven (eds.), Minnesota Studies in the Philosophy of Science, vol. 1, 253-329. Minneapolis: University of Minnesota Press.

Sextus Empiricus. 2000. Outlines of Scepticism, trans. J. Annas and J. Barnes. Cambridge: Cambridge University Press.

Stewart, Dugald. 2005. Dissertation on the Progress of Philosophy. In J. Fieser (ed.), Early Responses to Hume's Metaphysical and Epistemological Writings, II, 2nd. edition. Bristol: Thoemmes Press.

Thurber, James. 1942. “The day the dam broke.” In his My Life and Hard Times. New York: Harper Brothers.

Williams, Michael. 1988. "Scepticism without theory," The Review of Metaphysics 41: $547-588$. 
Wittgenstein, Ludwig. 1958. Philosophical Investigations, 3d. edition, G.E.M. Anscombe (trans.). NewYork: MacMillan. 